\title{
RESPON ADAPTASI MOLEKULER IMUNITAS TUBUH PENDUDUK YANG BERADA DI LINGKUNGAN TERPAPAR POLUSI UDARA
}

\author{
M. Zulkarnain, ${ }^{1}$ Rostika Flora ${ }^{2}$ \\ ${ }^{1}$ Departemen Ilmu Kesehatan Masyarakat, Fakultas Kedokteran, Universitas Sriwijaya \\ ${ }^{2}$ Fakultas Kesehatan Masyarakat, Universitas Sriwijaya \\ MOLECULAR ADAPTATION RESPONSE OF IMMUNITY SYSTEM \\ ON POPULATION EXPOSED TO AIR POLLUTION
}

\begin{abstract}
Background: Industry in various regions of the world has been very influential with the emissions of various substances that are air pollutants and increase air pollution. Continuous exposure to air pollution can lead to decrease the immune system. The purpose of this research is to know the molecular response of immunity of body residing in environment exposed to air pollution

Method: The type of this research is observational analytic by using cross sectional approach. The sample of this study amounted to 60 people living around the Rubber Factory Gandus and TPA Sukawinatan garbage Palembang. Examination of TNF- $\alpha$ and IL-6 levels using ELISA Human kit technique. Measurement of H2S at a distance of 250 meters, with methylene blue method.

Result: H2S levels in the area around the Sukawinatan Wastewater Disposal $(0,428$ ppm) are higher than in the Gandus Rubber Factory ( 0,332 ppm). There was no significant difference between mean of TNF- $\alpha$ level $(p=0,701)$ and mean of IL-6 level $(p=0,618)$. The correlation values of respondent characteristics with TNF$\alpha$ and IL-6 levels in the two study sites were very weak and not statistically significant. The correlation value between IL-6 is very weak and statistically significant around the Gandus Rubber Plant $(r=0.284 ; p=0.128)$ and around the Sukawinatan waste disposal site $(r=-0.258 ; p=0.169)$.

Conclusio: Even though H2S levels in the area around the Sukawinatan Wastewater Landfill are higher than in the Gandus Rubber Factory, it is expected that the residents who are around rubber and waste landfill sites use personal protective equipment such as masks when outside the house and keep their nutritional intake well so that the immune system is awake
\end{abstract}

Keywords: Hidrogen sulfida, tumor necrosis factor-alpha, interleukin-6

\begin{abstract}
ABSTRAK
Latar Belakang: Perindustrian di berbagai wilayah dunia telah berpengaruh terhadap polusi atau pencemaran udara. Paparan polusi udara secara terus-menerus dapat mengakibatkan penurunan sistem imun. Tujuan penelitian ini adalah untuk mengetahui respon molekuler imunitas tubuh penduduk yang berada di lingkungan terpapar polusi udara.

Metode: Jenis penelitian ini adalah observasional analitik dengan rancangan cross sectional. Populasi penelitian ini adalah seluruh masyarakat yang tinggal di sekitar Pabrik Karet Gandus dan TPA sampah Sukawinatan Palembang yang berjumlah 60 orang yang memenuhi kriteria inklusi. Pemeriksaan kadar TNF$\alpha$ dan IL-6 menggunakan teknik ELISA Human kit, pengukuran kadar $\mathrm{H}_{2} \mathrm{~S}$ dilakukan pada jarak 250 meter, dengan metode biru metilen.

Hasil Penelitian: Kadar $\mathrm{H}_{2} \mathrm{~S}$ di sekitar TPA Sampah Sukawinatan $(0,428 \mathrm{ppm})$ lebih tinggi dibandingkan kadar $\mathrm{H}_{2} \mathrm{~S}$ disekitar Pabrik Karet Gandus $(0,332 \mathrm{ppm})$. Tidak terdapat perbedaan yang bermakna rerata kadar TNF- $\alpha(p=0,701)$ dan rerata kadar IL- $6(p=0,618)$ antara kedua lokasi. Nilai korelasi karakteristik responden dengan kadar TNF- $\alpha$ dan kadar IL-6 di dua lokasi penelitian sangat lemah dan tidak bermakna secara statistik. Nilai korelasi antara dengan IL-6 sangat lemah dan tidak bermakna secara statistik di sekitar Pabrik Karet Gandus ( $r=0,284 ; p=0,128)$ dan di sekitar TPA sampah Sukawinatan $(r=-0,258 ; p=0,169)$.

Kesimpulan: Meskipun kadar $\mathrm{H}_{2} \mathrm{~S}$ di sekitar TPA Sampah Sukawinatan lebih tinggi, diharapkan penduduk yang berada disekitar Pabrik karet dan TPA sampah menggunakan alat pelindung diri seperti masker saat berada diluar rumah dan menjaga asupan nutrisi dengan baik agar kekebalan tubuh terjaga.
\end{abstract}

Kata kunci: Hidrogen Sulfida, tumor necrosis factor-alpha, interleukin-6.

Alamat Koresponding: Rostika Flora, Fakultas Kesehatan Masyarakat, Universitas Sriwijaya, Jalan Padang Selasa,No.524, Bukit Lama Ilir Barat I Palembang , Email: rostikaflora@gmail.com 


\section{PENDAHULUAN}

Pencemaran udara merupakan salah satu masalah kesehatan masyarakat yang penting, terutama di negara berkembang. Perkembangan ekonomi, kepadatan penduduk, urbanisasi, penggunaan energi, dan transportasi menjadi penyebab utama terjadinya polusi udara di negara berkembang terutama di kota-kota besar. ${ }^{1}$ Pencemaran udara dapat bersumber dari berbagai sumber, antara lain: asap kendaraan bermotor, asap pabrik, limbah industri, limbah rumah tangga yang berada di tempat pembuangan akhir (TPA) sampah dan lain-lain. ${ }^{2}$

Sampah merupakan salah satu sumber pencemaran udara yang menghasilkan gas amonia $\left(\mathrm{NH}_{3}\right)$ dan gas hidrogen sulfida $\left(\mathrm{H}_{2} \mathrm{~S}\right)$ yang terlepas ke udara akibat dari proses dekomposisi sampah. Hal ini dapat mengakibatkan udara di sekitar TPA menjadi bau dan kualitas udara ambien menurun. ${ }^{3}$ Selain TPA Sampah, pabrik karet menghasilkan gas $\mathrm{H}_{2} \mathrm{~S}$ yang ditimbulkan dari gradasi protein pada lateks. Lateks yang tidak banyak memiliki oksigen dan adanya organisme di dalam lateks mengakibatkan terbentuknya gas $\mathrm{H}_{2} \mathrm{~S}{ }^{4}$

Hidrogen sulfida $\left(\mathrm{H}_{2} \mathrm{~S}\right)$ merupakan gas yang tidak berwarna, sangat beracun, mudah terbakar dan memiliki karakteristik bau telur busuk. Gas ini dapat menyebabkan dampak yang buruk bagi kesehatan. Paparan gas $\mathrm{H}_{2} \mathrm{~S}$ dapat masuk melalui paru-paru melalui proses inhalasi. Pada konsentrasi rendah dapat menyebabkan iritasi mata, hidung dan kerongkongan, bahkan dapat terjadi kesulitan pernapasan. $^{5}$ Hidrogen sulfida $\left(\mathrm{H}_{2} \mathrm{~S}\right)$ menghambat enzim cytochrome oxidase sebagai penghasil oksigen sel. Metabolisme anaerobik menyebabkan akumulasi asam laktat yang mendorong ke arah ketidakseimbangan asam-basa. Sistem jaringan saraf berhubungan dengan jantung terutama sekali peka kepada gangguan metabolisme oksidasi, sehingga terjadi kematian dan terhentinya pernapasan. ${ }^{5}$
Paparan polusi udara dapat mengakibatkan penurunan sistem imun. Ketika sistem imun menurun maka tubuh akan lebih mudah terserang penyakit. Hal ini menyebabkan TNF- $\alpha$ diproduksi secara berlebihan dan kadar TNF- $\alpha$ meningkat. ${ }^{6}$ Tumor Necrosis Factor (TNF- $\alpha$ ) merupakan sitokin proinflamasi yang mempunyai efek agregasi dan aktivasi neutrofil. Selain itu, TNF- $\alpha$ juga dapat mengaktivasi endotel dengan cara meningkatkan pengeluaran molekul adhesi yang berguna pada saat sekuestrasi sel radang pada sel target. ${ }^{7}$

Interleukin-6 (IL-6) adalah sitokin yang memodulasi beberapa fungsi, seperti proliferasi, diferensiasi sel, dan apoptosis. Terlepas dari aksinya dalam peradangan, IL6 juga mempengaruhi berbagai sistem, termasuk sistem saraf dan endokrin, metabolisme tulang dan otot rangka. ${ }^{8}$ Interleukin-6 (IL-6) diduga memainkan memicu proses inflamasi. ${ }^{9}$ Bukti menunjukkan bahwa inflamasi dari polusi udara dapat menginduksi ekspresi genetik Interleukin-6 (IL-6). ${ }^{10}$

Paparan polusi udara secara terusmenerus mengakibatkan timbulnya respon adaptasi molekuler tubuh. Adaptasi molekuler tubuh berperan untuk mengatasi terjadinya penurunan sistem imun. Apabila terjadi penurunan sistem imun tubuh, maka akan berdampak terhadap timbulnya berbagai macam penyakit. Untuk melawan berbagai penyakit, maka TNF- $\alpha$ diproduksi secara berlebihan. Selain TNF- $\alpha$, IL-6 juga berperan sebagai mediator inflamasi dan memainkan peran sentral dalam memicu proses inflamasi. Diduga, pada penduduk yang berada di sekitar pabrik karet dan TPA sampah akan terjadi respon adaptasi molekuler tersebut. Penelitian ini bertujuan untuk mengetahui respon molekuler imunitas tubuh penduduk yang berada di lingkungan terpapar polusi udara. 


\section{METODE}

Jenis penelitian ini adalah jenis penelitian observasional analitik dengan menggunakan pendekatan cross sectional, dimana variabel independen (Kadar zat polutan $\mathrm{H}_{2} \mathrm{~S}$ ) dan variabel dependen (Kadar TNF- $\alpha$ dan IL-6 plasma manusia) diukur dalam waktu yang bersamaan. Penelitian ini dilaksanakan pada bulan Mei - Juni 2016 di Pabrik Karet Gandus dan Tempat Pembuangan Akhir (TPA) Sampah Sukawinatan Palembang.Populasi dalam penelitian ini adalah seluruh masyarakat yang tinggal di sekitar Pabrik Karet Gandus dan TPA Sampah Sukawinatan Palembang. Sampel penelitian ini berjumlah 60 orang yang memenuhi kriteria inklusi yaitu masyarakat yang berusia 18 - 30 tahun, tidak merokok, tidak mengkonsumsi obat-obatan anti inflamasi, dan telah bermukim minimal 3 tahun.

Penelitian ini menggunakan data primer yaitu melakukan pemeriksaan kadar TNF- $\alpha$ dan IL-6 menggunakan teknik ELISA
Human kit dengan mengambil sampel darah di vena mediana cubiti sebanyak $2,5 \mathrm{cc}$. Pembacaan hasil pemeriksaan kadar TNF- $\alpha$ dan IL-6 menggunakan alat ELISA Raider. Pengukuran kadar $\mathrm{H}_{2} \mathrm{~S}$ dilakukan di dua tempat yaitu Pabrik Karet Gandus dan TPA Sampah Sukawinatan. Pengukuran dilakukan pada jarak 250 meter, dengan metode biru metilen. Setelah data terkumpul dilakukan analisis secara univariat (mean dan standar deviasi) dan bivariat (uji t dan uji korelasi) secara komputerisasi.

\section{HASIL PENELITIAN}

Karakteristik dari 60 responden yang berada di sekitar Pabrik Karet Gandus dan TPA Sampah Sukawinatan dapat dijelaskan pada tabel berikut ini:

Tabel 1.

Karakteristik Subjek Penelitian

\begin{tabular}{lcc}
\hline Karakteristik & $\begin{array}{c}\text { Pabrik Karet } \\
\text { Gandus }(\mathbf{n}=\mathbf{3 0}) \\
\text { Mean } \pm \text { SD }\end{array}$ & $\begin{array}{c}\text { TPA Sampah } \\
\text { Sukawinatan } \\
(\mathbf{n}=30) \\
\text { Mean } \pm \text { SD }\end{array}$ \\
\hline Umur & $24,7 \pm 4,2$ & $23,8 \pm 4,5$ \\
Tinggi Badan & $156,4 \pm 6,7$ & $157,2 \pm 6,9$ \\
Berat Badan & $60,7 \pm 10,9$ & $52,2 \pm 10,3$ \\
\hline
\end{tabular}

Hasil penelitian pada Tabel 1 . menunjukkan bahwa, rerata umur penduduk yang berada di sekitar Pabrik Karet Gandus dan TPA Sampah Sukawinatan berada pada rentang 23,77-24,77 tahun, rata-rata tinggi badan responden $156-157 \mathrm{~cm}$, berat badan berada pada rentang $52-60 \mathrm{~kg}$.

Pengukuran kadar $\mathrm{H}_{2} \mathrm{~S}$ yang diukur pada jarak 250 meter didapatkan hasil sebagai berikut :
Tabel 2.

Kadar H2S pada Pabrik Karet Gandus dan TPA Sampah Sukawinatan

\begin{tabular}{cc}
\hline $\begin{array}{c}\text { Pabrik Karet } \\
\text { Gandus (ppm) }\end{array}$ & $\begin{array}{c}\text { TPA Sampah } \\
\text { Sukawinatan (ppm) }\end{array}$ \\
\hline 0,332 & 0,482 \\
\hline
\end{tabular}

Tabel 2. menunjukkan bahwa, kadar $\mathrm{H}_{2} \mathrm{~S}$ pada daerah sekitar TPA Sampah Sukawinatan lebih tinggi dibandingkan pada Pabrik Karet Gandus. 
Tabel 3.

Perbedaan Rerata KadarTNF- $\alpha$ dan Kadar IL-6 antara Penduduk yang berada di Sekitar Pabrik Karet Gandus dengan Penduduk di TPA Sampah Sukawinatan

\begin{tabular}{llc}
\hline \multirow{2}{*}{$\begin{array}{l}\text { Hasil } \\
\text { Pemeriksaan }\end{array}$} & \multicolumn{2}{c}{ Lokasi Penelitian } \\
\cline { 2 - 3 } $\begin{array}{l}\text { Kadar TNF- } \alpha \\
\text { (mean } \pm \text { SD) }\end{array}$ & Pabrik Karet & TPA \\
\hline$p$ value* TNF- $\alpha$ & $45,9 \pm 15,3$ \\
\hline $\begin{array}{l}\text { Kadar IL-6 } \\
\text { (mean } \pm \text { SD) }\end{array}$ & $3,3 \pm 1,4$ & 0,701 \\
\hline$p$ value* IL-6 & $3,1 \pm 1,2$ \\
\hline$p^{*}$ Uji Mann-Withney $(p<0,05)$ & 0,618 \\
\hline
\end{tabular}

Berdasarkan Tabel 3. didapatkan bahwa,rerata kadar TNF- $\alpha$ plasma pada penduduk yang berada di sekitar TPA Sampah Sukawinatan lebih tinggi dibandingkan pada penduduk yang berada di sekitar Pabrik Karet Gandus. Hasil analisis bivariat menggunakan uji t alternatif (MannWhitney) didapatkan bahwa tidak terdapat perbedaan yang bermakna $(\mathrm{p}=>0,05)$ rerata kadar TNF- $\alpha$ antara penduduk yang berada di sekitar Pabrik Karet Gandus dengan penduduk di TPA Sampah Sukawinatan.

Pada Tabel 3 juga didapatkan rerata kadar IL-6 plasma pada penduduk yang berada di sekitar Pabrik Karet Gandus lebih tinggi dibandingkan TPA Sampah Sukawintan. Hasil analisis bivariat menggunakan uji $\mathrm{t}$ tidak berpasangan didapatkan bahwa tidak terdapat perbedaan yang bermakna $(p>0,05)$ rerata kadar IL-6 antara penduduk yang berada di sekitar Pabrik Karet Gandus dengan penduduk di TPA Sampah Sukawinatan.

Untuk mengetahui kekuatan korelasi antara dua variabel numerik (kadar TNF- $\alpha$ plasma dan kadar IL-6 plasma) dengan menggunakan uji korelasi spearman dapat dilihat pada tabel 4 berikut :
Tabel 4.

Korelasi antara Karakteristik Responden dengan Kadar TNF- $\alpha$ antara Penduduk yang berada di Sekitar Pabrik Gandus dengan Penduduk di TPA Sampah Sukawinatan

\begin{tabular}{cccc}
\hline \multirow{2}{*}{ Karakteristik } & \multicolumn{3}{c}{ KadarTNF- $\alpha$} \\
\cline { 2 - 4 } & $\begin{array}{c}\boldsymbol{p} \\
\text { value }\end{array}$ & $\begin{array}{c}\text { Nilai } \\
\text { Korelasi }\end{array}$ & $\begin{array}{c}\text { Tingkat } \\
\text { Korelasi }\end{array}$ \\
\hline Usia & 0,932 & 0,011 & Sangat lemah \\
& & & \\
\hline TB & 0,502 & $-0,088$ & Sangat lemah \\
\hline BB & 0,999 & 0,000 & Sangat lemah \\
\hline
\end{tabular}

*Uji Korelasi Spearman $(p<0,05)$

Tabel 4. menunjukkan bahwa tidak terdapat korelasi yang bermakna antara karakteristik responden (usia, TB dan BB) dengan kadar TNF- $\alpha$ plasma pada penduduk yang berada di sekitar Pabrik Karet Gandus dan TPA Sampah Sukawinatan

Tabel 5.

Korelasi antara Karakteristik Responden dengan Kadar IL-6 antara Penduduk yang beradadi Sekitar Pabrik Karet Gandus dengan Penduduk di TPA Sampah Sukawinatan

\begin{tabular}{lccc}
\hline \multirow{2}{*}{ Karakteristik } & \multicolumn{3}{c}{ Kadar IL-6 } \\
\cline { 2 - 4 } & $\begin{array}{c}\boldsymbol{p} \\
\text { value }\end{array}$ & $\begin{array}{c}\text { Nilai } \\
\text { Korelasi }\end{array}$ & $\begin{array}{c}\text { Tingkat } \\
\text { Korelasi }\end{array}$ \\
\hline Usia & 0,299 & $-0,136$ & $\begin{array}{l}\text { Sangat } \\
\text { lemah }\end{array}$ \\
TB & 0,686 & $-0,053$ & $\begin{array}{l}\text { Sangat } \\
\text { lemah }\end{array}$ \\
BB & 0,280 & $-0,142$ & $\begin{array}{l}\text { Sangat } \\
\text { lemah }\end{array}$ \\
\hline
\end{tabular}

*Uji Korelasi Spearman $(p<0,05)$

Tabel 5. menunjukkan bahwa tidak terdapat korelasi yang bermakna antara karakteristik responden (usia, TB dan BB) dengan Kadar IL-6plasma pada penduduk yang berada di sekitar Pabrik Karet Gandus dan TPA Sampah Sukawinatan. 
Tabel 6.

Korelasi Antara Rerata Kadar TNF- $\alpha$ dan Kadar IL-6 antara Penduduk yang berada di Sekitar Pabrik Karet Gandus dengan Penduduk di TPA Sampah Sukawinatan

\begin{tabular}{|c|c|c|c|c|}
\hline \multirow{3}{*}{$\begin{array}{c}\text { Hasil } \\
\text { Analisis }\end{array}$} & \multicolumn{4}{|c|}{ Lokasi Penelitian } \\
\hline & \multicolumn{2}{|c|}{ Pabrik Karet } & \multicolumn{2}{|c|}{ TPA } \\
\hline & TNF- $\alpha$ & IL-6 & TNF- $\alpha$ & IL-6 \\
\hline $\begin{array}{l}\text { Mean } \pm \\
\text { SD }\end{array}$ & $\begin{array}{c}44,4 \\
\pm 12,5\end{array}$ & $3,3 \pm 1,4$ & $\begin{array}{c}45,9 \\
\pm 15,3\end{array}$ & $3,1 \pm 1,2$ \\
\hline p value & \multicolumn{2}{|c|}{0,128} & \multicolumn{2}{|c|}{0,169} \\
\hline $\begin{array}{l}\text { Nilai } \\
\text { Korelasi }\end{array}$ & \multicolumn{2}{|c|}{0,284} & \multicolumn{2}{|c|}{$-0,258$} \\
\hline $\begin{array}{l}\text { Tingkat } \\
\text { Korelasi }\end{array}$ & \multicolumn{2}{|c|}{ Sangat lemah } & \multicolumn{2}{|c|}{ Sangat lemah } \\
\hline
\end{tabular}

Tabel 6. menunjukkan bahwa, tidak terdapat korelasi yang bermakna antara Kadar TNF- $\alpha$ plasma dengan Kadar IL-6 plasma pada penduduk yang berada di sekitar Pabrik Karet Gandus dan TPA Sampah Sukawinatan.

\section{PEMBAHASAN}

Berdasarkan hasil penelitian yang telah dilakukan didapatkan bahwa kadar $\mathrm{H}_{2} \mathrm{~S}$ pada pabrik karet gandus 0,332 ppm dan TPA sampah sukawinatan $0,482 \mathrm{ppm}$, nilai kadar ini 16 kali melebihi nilai ambang batas kadar $\mathrm{H}_{2} \mathrm{~S}$ yakni $0,02 \mathrm{ppm}$. Hasil penelitian yang dilakukan oleh Sianipar, ${ }^{11}$ yang menyatakan bahwa terdapat perbedaan yang bermakna $(\mathrm{p}<0,05)$ konsentrasi $\mathrm{H}_{2} \mathrm{~S}$ di TPA Terjun dan di luar TPA Terjun. Hal ini ditunjukkan dengan rata-rata konsentrasi $\mathrm{H}_{2} \mathrm{~S}$ di TPA Terjun adalah $0,0290 \mathrm{mg} / \mathrm{m}^{3}(\mathrm{SD}=0,02023)$ dan di luar TPA Terjun adalah $0,0033 \mathrm{mg} / \mathrm{m}^{3}$ $(\mathrm{SD}=0,00057)$. Diduga, peningkatan kadar $\mathrm{H}_{2} \mathrm{~S}$ yang terjadi dikarenakan sistem pengelolaan sampah pada TPA Sampah Sukawinatan dilakukan secara open dumping.

Menurut Sastrawijaya, ${ }^{12}$ open dumping adalah sistem pembuangan sampah yang hanya dibuang disuatu tempat tanpa ada perlakuan khusus. Sistem pembuangan ini dapat menimbulkan gangguan terhadap lingkungan, terutama pencemaran udara. Hal inilah yang menyebabkan udara disekitar TPA Sampah Sukawinatan tercemar oleh
$\mathrm{H}_{2} \mathrm{~S}$ dan berbau tidak sedap. Pembuangan sampah secara terbuka dapat menjadi sarang /tempat perkembangan vektor penyakit (lalat, tikus, kecoa), menyebarkan bau, mencemari udara, air permukaan dan air tanah, bahaya kebakaran dan menimbulkan asap tebal yang berkepanjangan.

Oleh karena potensi pencemarannya terhadap lingkungan tinggi, maka sistem pembuangan sampah open dumping ini lokasinya harus berjauhan dari wilayah pemukiman kota dan berada pada lahan yang relatif luas. TPA Sampah Sukawinatan pada awalnya berada jauh dari pusat kota, akan tetapi dengan bertambah pesatnya jumlah penduduk mengakibatkan daerah sekitar TPA Sampah Sukawinatan menjadi daerah pemukiman penduduk.

Hasil studi pendahuluan yang dilakukan menunjukkan bahwa, pada awalnya penduduk merasa terganggu dengan pencemaran udara tersebut. Akan tetapi setelah menetap dalam waktu yang lama, penduduk terbiasa dengan pencemaran udara yang berasal dari gas $\mathrm{H}_{2} \mathrm{~S}$. Gas $\mathrm{H}_{2} \mathrm{~S}$ timbul dari aktivitas biologis ketika bakteri mengurai bahan organik dalam keadaan tanpa oksigen (aktivitas anaerobic). ${ }^{13}$

Pencemaran udara pada dasarnya berbentuk partikel (debu, aerosol, timah hitam) dan gas (CO, NOx, SOx, H2S, hidrokarbon). Udara yang tercemar dengan partikel dan gas ini dapat menyebabkan gangguan kesehatan yang berbeda tingkatan dan jenisnya, tergantung dari macam, ukuran dan komposisi kimiawinya. Gangguan tersebut terutama terjadi pada fungsi faal dari organ tubuh seperti paru-paru dan pembuluh darah atau menyebabkan iritasi pada mata dan kulit. Pencemar gas yang terlarut dalam udara dapat langsung masuk kedalam tubuh sampai ke paru-paru yang pada akhirnya diserap oleh sistem peredaran darah. ${ }^{14}$

Gas Hidrogen sulfida merupakan gas yang tidak berwarna, sangat beracun, mudah terbakar dan memiliki karakteristik bau telur busuk. Bau telur busuk akan muncul apabila $\geq 0,13$ ppm. ${ }^{15} \mathrm{H}_{2} \mathrm{~S}$ pada kadar $0,05 \mathrm{ppm}$ 
dapat dideteksi dari bau, dan pada kadar 0,1 ppm mengakibatkan iritasi dan kehilangan rasa sensoris. Setelah mengalami pemajanan pada kadar diatas $50 \mathrm{ppm}$, gejala secara bertahap akan naik, conjungtivitis yang nyeri, pusing, anosmia, mual, batuk, radang tenggorokan dan edema paru. Pada kadar 500 ppm akan terjadi kehilangan kesadaran mendadak, depresi pernafasan dan akan meninggal dalam waktu 30-60 menit. ${ }^{16}$ Potensi bahaya $\mathrm{H}_{2} \mathrm{~S}$, CO dan $\mathrm{NH} 3$ dapat terjadi pada pekerja yang bekerja di tempat penyulingan di Instalasi Industri PT Pertamina Plaju Palembang. ${ }^{17}$

Menurut penelitian Mardiani, ${ }^{18}$ tentang Hubungan Kualitas Udara Ambein dan Vektor terhadap Gangguan Keluhan Saluran Pernafasan dan Saluran Pencernaan di Sekitar Tempat Pembuangan Akhir Sampah menunjukkan bahwa kadar gas $\mathrm{H}_{2} \mathrm{~S}$ terdeteksi melebihi Nilai Ambang Batas (NAB) pada radius 250 meter dari TPA. Studi AMDAL terhadap TPA Bantar Gebang Bekasi tahun 1989 menyatakan bahwa timbulnya pencemaran udara akibat meningkatnya konsentrasi gas disertai bau busuk, baik yang ditimbulkan tahap pembongkaran penimbunan dan pemadatan sampah maupun setelah selesainya tahap pembongkaran sampah. ${ }^{19}$

Begitu pula penelitian yang dilakukan oleh Meirinda, ${ }^{20}$ didapatkan bahwa, konsentrasi $\mathrm{H}_{2} \mathrm{~S}$ di TPA Sampah Terjun Kecamatan Medan Marelan berada di atas kadar maksimum yang diperbolehkan berdasarkan Keputusan Menteri Negara Kesehatan Lingkungan Hidup Nomor KEP50/MENLH/11/1996 Baku Tingkat Kebauan.

$\mathrm{Gas}_{2} \mathrm{~S}$ sangat berbahaya jika terhirup masuk ke saluran pernafasan. Jika jumlah gas $\mathrm{H}_{2} \mathrm{~S}$ yang terserap ke dalam sistem peredaran darah melampaui kemampuan oksidasi dalam darah maka akan menimbulkan keracunan terhadap sistem syaraf. Setelah itu secara singkat segera diikuti terjadinya sesak nafas dan kelumpuhan (paralisis) pernafasan pada konsentrasi tinggi. Jika penderita tidak segera dipindahkan ke ruangan berudara segar dan diberikan bantuan pernafasan maka akan segera terjadi kematian akibat kelemasan (asphyxiation). Pengaruh gas $\mathrm{H}_{2} \mathrm{~S}$ pada konsentrasi rendah akan mengakibatkan terjadinya gejala pusing, mual, rasa melayang, batuk-batuk, gelisah, mengantuk, rasa kering dan nyeri di hidung, tenggorokan, dan dada. ${ }^{21}$

Hasil penelitian menunjukkan bahwa,tidak terdapat perbedaan yang bermakna $(p>0,05)$ rerata kadar TNF- $\alpha$ dan rerata kadar IL-6pada penduduk yang berada di sekitar Pabrik Karet Gandus dan TPA Sampah Sukawinatan.

Rerata kadar TNF- $\alpha$ pada penduduk yang berada di sekitar Pabrik Karet Gandus dan TPA Sampah Sukawinatan menunjukkan rerata kadar masih dalam batas normal 20$400 \mathrm{ng} / \mathrm{L}$. Hasil penelitian ini sejalan dengan hasil penelitian Sack et al, ${ }^{22}$ yang meneliti kadar TNF- $\alpha$ pada 275 anak sehat dan membandingkannya dengan kadar pada serum orang dewasa yang sehat. Penelitian ini menunjukkan bahwa kadar TNF- $\alpha$ lebih tinggi daripada orang dewasa, mencapai puncak pada usia 13-14 tahun dan kemudian kadar ini menurun.

Hasil penelitian ini didapatkan bahwa tidak terdapat korelasi yang bermakna antara karakteristik responden (usia) dengan kadar TNF- $\alpha$ plasma dengan kadar IL-6. Hasil penelitian tidak sejalan dengan hasil penelitian Hartini \& Kumalasari ${ }^{23}$ yang menyatakan ada hubungan antara umur (pvalue $=0,026)$ dan masa kerja (pvalue $=$ 0,002 ) dengan keluhan gangguan kesehatan pada pemulung di TPA Jatibarang. Kadar gas amonia dan hidrogen sulfida di zona I dan II berada di bawah baku mutu. Rerata pemulung wanita berumur 39 tahun, masa kerja 10 tahun, 20 pemulung wanita memiliki pola paparan sedang dengan kriteria $\geq 8$ jam kerja per hari, $\geq 7$ hari kerja dalam seminggu, istirahat > 3 kali sehari, istirahat dalam satu kali $\geq 6-10$ menit dan $50 \%$ pemulung wanita beristirahat di area TPA

Hasil penelitian ini juga menunjukkan bahwa tidak terdapat korelasi yang bermakna 
antara karakteristik responden (Berat Badan) dengan kadar TNF- $\alpha$ dan IL-6. Berat badan tidak mempengaruhi imunitas tubuh penduduk di sekitar TPA, walaupun mereka tinggal di lingkungan terpapar polusi udara $\left(\mathrm{H}_{2} \mathrm{~S}\right)$. Hasil penelitian ini tidak sejalan dengan penelitan Arista $\mathrm{dkk}^{24}$ yang menyatakan bahwa 54,8\% Pedagang Kaki Lima (PKL) di Terminal Palembang Ampera yang memiliki rerata berat badan $65,57 \mathrm{~kg}$ beresiko 10 kali terpapar polusi udara (Sulfur Dioxide).

Hasil penelitian ini juga menunjukkan bahwa, tidak terdapat korelasi yang bermakna antara kadar TNF- $\alpha$ plasma dengan kadar IL-6 plasma dengan tingkat korelasi sangat lemah pada penduduk yang berada di sekitar Pabrik Karet Gandus maupun TPA Sampah Sukawinatan Palembang.

Hasil ini tidak sejalan dengan penelitian Chuang et $a l^{25}$ yang menyatakan bahwa, polusi udara kota selain berhubungan dengan inflamasi sistemik, perusakan sistem fibrinolitik, aktivasi sistem koagulasi darah, perubahan pada sistem saraf autonom pada orang dewasa juga berhubungan dengan kejadian stres oksidatif. Menurut Fatmah, ${ }^{6}$ terdapat faktor lain yang mempengaruhi kadar TNF- $\alpha$ yaitu faktor stres. Saat terjadi stres maka hormon glukokortikoid dan kortisol memicu reaksi anti-inflamasi sistem imun yang menyebabkan peningkatan kadar TNF- $\alpha$.

Tumor necrosis factor alpha (TNF- $\alpha$ ) merupakan sitokin proinflamasi yang pleiotropik. Sitokin ini mempengaruhi banyak organ dan memiliki banyak fungsi yang mekanismenya belum diketahui sepenuhnya. Mekanisme kerja TNF- $\alpha$ sama seperti sitokin lain, yaitu berperan sebagai sinyal secara lokal dari satu sel ke sel yang lain dalam meregulasi proses-proses biologis penting seperti pertumbuhan sel, aktivasi sel, peradangan, imunitas, perbaikan jaringan, fibrosis dan morfogenesis. ${ }^{25}$

Faktor Nekrosis Tumor $\alpha$ (TNF- $\alpha)$, merupakan sitokin yang diproduksi oleh berbagai tipe sel dan merupakan salah satu mediator imunologi yang pertamakali muncul akibat respons infeksi atau trauma. ${ }^{26}$ TNF- $\alpha$ juga berperan dalam respons adaptif terhadap inflamasi. ${ }^{27}$

TNF- $\alpha$ memiliki beberapa efek pada tubuh. Sewaktu dikeluarkan pada konsentrasi rendah, TNF- $\alpha$ bekerja pada sel endotel menyebabkan vasodilatasi dan menstimulasi sel ini untuk mensekresi grup leukosit kemotaksis sitokin yang dinamakan kemokin. Inflamasi lokal yang dihasilkan melawan infeksi. Pada hipotalamus TNF- $\alpha$ pirogen endogen yang menyebabkan demam. Pada hepar, TNF- $\alpha$ menstimulasi produksi acute phase inflammatory proteins dan fibrinogen. ${ }^{30}$ Infeksi berat dapat memicu produksi TNF- $\alpha$ dalam jumlah besar yang menimbulkan reaksi sistemik. ${ }^{31}$

TNF- $\alpha$ mempunyai beberapa fungsi dalam proses inflamasi, yaitu dapat meningkatkan peran pro trombotik dan merangsang molekul adhesi dari sel leukosit serta menginduksi sel endotel, berperan dalam mengatur aktivitas makrofag dan respon imun dalam jaringan dengan merangsang faktor pertumbuhan dan sitokin yang lain, berfungsi sebagai regulator dari hematopoitik serta komitogen untuk sel $\mathrm{T}$ dan sel B serta aktivitas sel neutrofil dan makrofag. TNF- $\alpha$ juga memiliki fungsi tambahan yang menguntungkan termasuk peranannya dalam respon imun terhadap bakteri, virus, jamur, dan invasi parasit. ${ }^{30}$

Fungsi menguntungkan tambahan TNF- $\alpha$ termasuk perannya dalam respon kekebalan terhadap bakteri dan jamur tertentu, invasi virus, dan parasit serta perannya dalam necrosis tumor tertentu. Terakhir ia bertindak sebagai mediary kunci dalam respon imun lokal inflamasi. TNF- $\alpha$ adalah protein fase akut yang memulai kaskade sitokin dan meningkatkan permeabilitas pembuluh darah, sehingga merekrut makrofag dan neutrofil ke situs infeksi. TNF- $\alpha$ disekresikan oleh makrofag menyebabkan pembekuan darah yang berfungsi mengandung infeksi. Tanpa TNF- 
$\alpha$, tikus yang terinfeksi dengan bakteri gram negatif mengalami syok septic. ${ }^{31}$

Hasil penelitian Ruckerl et $a, l^{34}$ menunjukkan bahwa peningkatan IL-6 ketika konsentrasi Particle Number Concentrations (PNC) meningkat 12-17 jam sebelum pengambilan darah. Lima hari paparan kumulatif terhadap Particulate Matter (PM10) dikaitkan dengan peningkatan konsentrasi fibrinogen

Berdasarkan hasil penelitian dapat disimpulkan bahwa korelasi antara karakteristik responden (usia, TB dan $\mathrm{BB}$ ) dengan kadar TNF- $\alpha$ dan IL-6 tidak bermakna secara statistik. Tidak terdapat perbedaan yang bermakna antara kadar TNF$\alpha$ dan IL-6 diantara dua lokasi penelitian. Hal ini kemungkinan dikarenakan sampel penelitian ini adalah kelompok umur dewasa muda yang sehat dan telah bermukim di daerah tersebut lebih dari 3 tahun, sehingga telah terbentuk mekanisme adaptasi tubuh terhadap paparan polusi udara

\section{KESIMPULAN DAN SARAN}

Hasil penelitian ini dapat disimpulkan sebagai berikut :

1. Rerata umur penduduk yang berada di sekitar Pabrik Karet Gandus dan TPA Sampah Sukawinatan berada pada rentang 23,77-24,77 tahun, tinggi badan responden $156-157 \mathrm{~cm}$, berat badan berada pada rentang 52-60 kg, serta lama tinggal penduduk berkisar 12,80-22,60 tahun

2. Kadar H2S pada daerah sekitar TPA Sampah Sukawinatan lebih tinggi dibandingkan pada Pabrik Karet Gandus.

3. Rerata kadar TNF- $\alpha$ plasma pada penduduk yang berada disekitar TPA Sampah Sukawinatan lebih tinggi dibandingkan penduduk yang berada di sekitar Pabrik Karet Gandus. Tidak terdapat perbedaan yang bermakna $(\mathrm{p}=0,701)$ rerata kadar TNF- $\alpha$ antara penduduk yang berada di sekitar Pabrik

\section{DAFTAR PUSTAKA}

Karet Gandus dengan penduduk di TPA Sampah Sukawinatan.

4. Rerata kadar IL-6 plasma pada penduduk yang berada di sekitar Pabrik Karet Gandus lebih tinggi dibandingkan TPA Sampah Sukawintan. Tidak terdapat perbedaan yang bermakna $(p=0,618)$ rerata kadar IL-6 antara penduduk yang berada di sekitar Pabrik Karet Gandus dengan penduduk di TPA Sampah Sukawinatan.

5. Nilai koefisien korelasi antara karakteristik responden dengan kadar TNF- $\alpha$ plasma sangat rendah diantaranya usia $(\mathrm{r}=0,011), \mathrm{TB}(\mathrm{r}=-0,088)$ dan $\mathrm{BB}$ $(\mathrm{r}=0,000)$ dan tidak bermakna secara statistik

6. Nilai koefisien korelasi antara karakteristik responden dengan kadar IL-6 plasma sangat rendah diantaranya usia $(\mathrm{r}=-0,136)$, $\mathrm{TB}(\mathrm{r}=-0,053)$ dan BB ( $\mathrm{r}=-$ $0,142)$ dan tidak bermakna secara statistik

7. Nilai koefisien korelasi antara KadarTNFa plasma dengan Kadar IL-6 plasmapada penduduk yang berada disekitar pabrik karet adalah 0,284 (korelasi lemah) dan tidak bermakna secara statistik ( $\mathrm{p}=0,128$ )

8. Nilai koefisien korelasi antara KadarTNF$\alpha$ plasma dengan Kadar IL-6plasmapada penduduk yang berada di TPA Sampah Sukawinatan adalah $-0,258$ (korelasi sangat lemah) dan tidak bermakna secara statistik ( $\mathrm{p}=0,169)$.

Saran dari penelitian diharapkan penduduk yang tinggal disekitar Pabrik Karet dan TPA sampah menggunakan Alat Pelindung Diri seperti masker saat berada di luar rumah dan menjaga asupan nutrisi dengan baik agar kekebalan tubuh tetap terjaga. 
1. Chen, B dan Kan, H. Air pollution and population health: a global challenge. Environ Health Prev Med. 2008 Mar; 13(2): 94-101.

2. Asri.Dampak Limbah dan Polusi terhadap Manusia dan Lingkungan. Alauddin University Press. Makssar. 2016.

3. Ballal, SG., et al.. Bronchial Asthma In Two Chemical Fertilizer Producing Factories In Eastern Saudi Arabia. Int J Tuberc Lung Dis, 1998. 2:330-335.

4. Sutedjo. M, Kartasapoetra, A.G dan Sastroamodjo, S. Mikrobiologi Tanah. Rineka Cipta. Jakarta. 1991.

5. U.S. EPA. Integrated Risk Information System Toxicity Summary for Hidrogen Sulfide. 2003.

6. Fatmah. Respons imunitas yang rendah pada tubuh manusia usia lanjut. Makara ; Jurnal Kesehatan. 2006.Vol. 10. No. 1. Depok : Universitas Indonesia.

7. Kumar V, Cotran RS, Robbins SL. Buku Ajar Patologi. Edisi ke-7. Jakarta : EGC 2007.

8. Peter FC, Scott Manaker MD, Holly Perry. Carbon monoxide poisoning. Wolters kluwer ; 2014.

9. Toumpanakis, D \& Vassilakopoulos, T. Molecular mechanisms of action of Interleukin-6 (IL-6). PNEUMON .2007. Number 2, Vol. 20, April - June 2007

10.Woods, L.J., Nail, L.M.,Winter, K.A. 2009. Does Muscle-Derived Interleukin-6 Mediate Some of The Beneficial Effects of Exercise on Cancer Treatment-Related Fatigue?. Oncol Nurs Forum. 2009 September: $\quad 36$ (5): 519-524.doi: 10.1188/09. ONF 519-524.

11.Ljungman, P., Bellander, T., Schneider, A., Breitner, S., Forastiere, F., Hampel, R., et al. Modification of the Interleukin-6 Response to Air Pollution by Interleukin-6 and Fibrinogen Polymorphisms. Environ Health Perspect. 2009 Sep; 117(9): 13731379.

12.Sianipar, RH. Analisis Risiko Paparan Hidrogen Sulfida pada Masyarakat Sekitar TPA Sampah Terjun Kecamatan Medan Marelan. [Tesis]. Medan : Universitas Sumatera Utara. 2009.

13.Sastrawijaya T. Pencemaran Lingkungan. Jakarta : PT. Rineka Cipta. 1991.
14.Sidik, R. 2014. Fakta Tentang H2S. https://id.linkedin.com/pulse/20141009024 735-230206347-fakta-tentang-h2s.

15.Ratnani, R.D. Teknik Pengendalian Pencemaran Udara yang Diakibatkan Oleh Partikel.Momentum, 2008. Vol. 4, No. 2, Oktober : $27-32$.

16.Agency for Toxic Substances and Disease Registry. Toxicological Profile For Hydrogen Sulfide.US Departement Of Health And Human Services. Public Health Service. Agency For Toxic Subtances And Disease Registry. 2003. http://www.atsdr.cdc.gov/toxprofiles/tp114 .pdf//. Diakses pada 10 April 2016.

17.Matariani,A., Hasyim.,H and Faisya, A.F. Control Analysis Of Hazards Potential In Crude Distiller Unit III PT. Pertamina (Persero) Refinery Unit Plaju Tahun 2011. Jurnal Ilmu Kesehatan Masyarakat Vol 3, No 3 (2012)Mardiani. 2008. Pengaruh Pemberian Timbal (Pb) terhadap Kadar Malondialdehyde (MDA) Plasma Mencit. Medan : Universitas Sumatera Utara.

18.Ditjen PPM \& PL. Parameter Pencemar Udara dan Dampaknya terhadap Kesehatan. Jakarta : Departemen Kesehatan RI. 2001.

19.Mardiani.. Pengaruh Pemberian Timbal (Pb) terhadap Kadar Malondialdehyde (MDA) Plasma Mencit. [Tesis]. Medan : Universitas Sumatera Utara. 2008.

20.Noriko, Nita. 2003. Tinjauan Akhir Tempat Pemusnahan Akhir Bantar Gebang Bekasi, Program Pasca Sarjana S3, Institut Pertanian Bogor. http://tumoutou.net/6 sem2 023/nita noriko.htm. di akses 10 April 2016.

21.Meirinda. Faktor-Faktor yang Berhubungan dengan Kualitas Udara dalam Rumah di Sekitar Tempat Pembuangan Akhir Sampah Kelurahan Terjun Kecamatan Medan Marelan. [Tesis]. Medan : Universitas Sumatera Utara. 2008.

22.Hartini, E \& Kumalasari, R.J. Faktor Faktor Risiko Paparan Gas Amonia dan Hidrogen Sulfida terhadap Keluhan Gangguan Kesehatan pada Pemulung di TPA Jatibarang Kota Semarang. [Tesis]. Semarang. Fakultas Kesehatan Universitas Dian Nuswantoro. 2014.

23.Arista,G., Sunarsih,E and Mutahar, R. Environmental Health Risk Analysis 
Exposure To Nitrogen Dioxide (No2) And Sulfur Dioxide (So2) On Street Vendor In Ampera Terminal Palembang 2015. Jurnal Ilmu Kesehatan Masyarakat. Vol 6, No 2. 2015

24.Jauhari, A. Mewaspadai Racun H2S yang Mematikan. Enviro. 2008

25.Sack U, Burkhardt U, Borte M, Schadlich H, Berg H, Emmerich F.. Age-Dependent Levels of Select Immunological Mediators in Sera of Healthy Children. Clin Diag lab Immunol.1998. 5 (1): 28-32

26.Chuang, M. T., Lin, Y. S., Hou, W. C. Ancordin The Major Rhizome Protein Of Madeira vine, With Trypsin Inhibitory and Stimulatory Activities in Nitrit Oxide Production. 2007. Peptides. 28 (6):1311-6.

27.Roitt I, Brostoff J, Male D. Immunology. $4^{\text {th }}$ edition. London. 1998

28. Steel DM, Whitehead S. The major acute phase reactans : C-reactive protein, serum amyloid $\mathrm{p}$ component and serum amyloid a protein. Immunology Today. 1994.

29. Bazan NG, Rodriguez de Turco EB, Allan G. Mediators of injury in neurotrauma: intracellular signal transduction and gene Expression, J Neurotrauma. 1995.
30. Vitale, RF \& Ribeiro, FA. The role of tumor necrosis factor-alpha (TNF-alpha) in bone resorption present in middle ear cholesteatoma', Braz J Otorhinolaryngol. 2007.Vol. 73, no.1.

31.Baratawidjaja, KG., Rengganis, Iris. Imunologi Dasar. Edisi ke-10. Jakarta : FKUI. 2012.

32. Yani L, Ilhamjaya P, Gatot SL, Wijaya A, Suryani A. Korelasi antara adiponektin dengan Tumor Necrosis Factor $\alpha$ (TNF- $\alpha$ ) pada pria Indonesia obes non diabetes. MKI. 2011.

33.Locksley RM., Killeen N., Lenardo MJ. 2001. The TNF and TNF receptor superfamilies: integrating mammalian biology. Cell. 2001 Feb 23;104(4):487501.

34. Rückerl, R., Greven, S., Ljungman, P., Aalto, P., Antoniades, C., Bellander, T et al. Air Pollution and Inflammation (Interleukin-6, C-Reactive Protein, Fibrinogen) in Myocardial Infarction Survivor. Environmental Health Perspective 2007. 7 July.Volume 115. 